\title{
Characterisation of a 5.5-kb cryptic plasmid present in different isolates of Bacteroides spp. originating from Hungary
}

\author{
J. SOKI, I. SZÖKE and ELISABETH NAGY \\ Department of Clinical Microbiology, Albert Szent-Györgyi Medical University, Szeged, Hungary
}

\begin{abstract}
The plasmid profiles of 97 Bacteroides isolates collected during screening for different pathogenic markers of this genus were investigated. In all, $48 \%$ of 69 isolates from infections that belonged to six species harboured low mol.wt plasmids $(2.8-11.0 \mathrm{~kb})$. Similar plasmids were also found in $39 \%$ of 28 isolates, belonging to eight species, from faeces of healthy persons. The two most frequently obtained types were the 5.5- and the 4.2-kb plasmids, which were present in $70 \%$ and $52 \%$ of all plasmid-bearing isolates, respectively. Restriction endonuclease analysis revealed that the 5.5-kb plasmids found in the different Bacteroides spp. exhibited the same restriction map, with the exception that pBVP61 lacked the Pst I recognition site. The two plasmid types $(4.2$ and $5.5 \mathrm{~kb}) \mathrm{seem}$ to be most widely distributed among Bacteroides isolates independent of the site of isolation and with some differences depending on geographic regions.
\end{abstract}

\section{Introduction}

Species of the genus Bacteroides are important constituents of the human and animal intestinal microflora, accounting for c. $30 \%$ of the total organisms cultured from faeces. Although different species of Bacteroides play several important roles in the normal intestinal activities, they are also the most frequently isolated anaerobic bacteria of clinical relevance. They can cause serious infections such as brain, lung, intra-abdominal and intra-pelvic abscesses, peritonitis and sepsis [1], where $B$. fragilis in most cases outnumbers other related species. Phylogenetically, together with Flavobacterium, Porphyromonas and Fusobacterium, they form an ancient and distinct group of eubacteria [2]. A high proportion of them carry low mol.wt plasmids to which no function has yet been assigned [3, 4]. About $26-50 \%$ of Bacteroides isolates from different species isolated from infections have been shown to exhibit such plasmids. Southern hybridisation has revealed that they are mainly from three groups [5]: class I (1.8 MDa), class II (2.6-4 $\mathrm{MDa})$ and class III (3.7 MDa). The pB8-51 4.2-kb (class II) cryptic Bacteroides plasmids were found to be the most prevalent in colonic Bacteroides isolates [6]. During an earlier study in this laboratory, 26 of 52 Bacteroides isolates from different serious infections, harboured one or more low mol. wt plasmids [4]. The

Received 23 Feb. 1998; accepted 17 April 1998. Corresponding author: Dr E. Nagy. type found most frequently in this group of isolates was a 3.7-MDa plasmid, which was present in $66 \%$ of the isolates containing plasmids. Only one $B$. vulgatus isolate from an intra-abdominal infection harboured the 2.6-MDa plasmid.

The aims of the present study were to compare the plasmid content of Bacteroides isolates originating from serious infections and from faeces of healthy persons, to compare the plasmid content of isolates with different pathogenicity determinants and to characterise a 5.5-kb plasmid found most frequently in isolates of different origins.

\section{Materials and methods}

\section{Bacterial isolates}

Bacteroides spp. involved in infectious processes (69 isolates) were isolated in different laboratories in Hungary; those from the faeces of healthy persons $(\mathrm{n}=28)$ were isolated in this laboratory. Bacteria were cultured in brain-heart infusion (BHI) broth and on BHI agar, supplemented with vitamin $\mathrm{K} 1$ and cow's blood, in an anaerobic chamber (Sheldon, USA) at $37^{\circ} \mathrm{C}$ for $48 \mathrm{~h}$. Isolates were identified with the ATB (bioMérieux) system and by conventional methods [7]. These isolates were initially collected to screen for different pathogenicity markers, such as toxin production of $B$. fragilis isolates, the binding of physiological matrix proteins to different Bacteroides species, and 
evaluation of antibiotic resistance. The isolates from normal faeces were: B. fragilis (15), B. vulgatus (3), B. ovatus (3), Mitsuokella (B.) multiacidus (2), B. eggerthii (2), B. stercoris (1), B. distasonis (1) and $B$. merdae (1), while the 69 isolates from different infections comprised $B$. fragilis (51), B. ovatus (8), B. vulgatus (5), B. thetaiotaomicron (2), B. caccae (2) and $B$. distasonis (1). Escherichia coli strains V/517 and 39R861 with reference mol. wt plasmids, and strain JM107 containing the pUC19 plasmid were propagated in Mueller-Hinton broth at $37^{\circ} \mathrm{C}$ overnight.

\section{Plasmid detection}

Plasmid screening was performed by the alkaline-SDS method of Birnboim and Doly [8]. E. coli reference plasmids were isolated by the same method. Bacteroides plasmids used for restriction endonuclease analysis were isolated by the method of Zöllner et al. [9]. Briefly, cells were cultured in $10 \mathrm{ml}$ of BHI broth for $24 \mathrm{~h}$ in an anaerobic environment. After further incubation in the presence of chloramphenicol $170 \mathrm{mg} / \mathrm{L}$ for $24 \mathrm{~h}$, the cells were pelleted by centrifugation and then resuspended in $100 \mu \mathrm{l}$ of $50 \mathrm{mM}$ Tris-HCl buffer, $\mathrm{pH}$ 8.0. Samples were heated to $95^{\circ} \mathrm{C}$, and $100 \mu \mathrm{l}$ of SDS 3\%, $50 \mathrm{mM}$ Tris/HC1, pH 12.6, buffer were added and incubated at $90^{\circ} \mathrm{C}$ for $5 \mathrm{~min}$. Samples were placed on ice, $100 \mu \mathrm{l}$ of $3 \mathrm{M}$ sodium acetate $(\mathrm{pH} \mathrm{4.8)}$ were added and the mixtures were held at $0^{\circ} \mathrm{C}$ for $30 \mathrm{~min}$. The precipitate was removed by centrifugation at $12000 \mathrm{rpm}$ at $4^{\circ} \mathrm{C}$ for $12 \mathrm{~min}$. The cleared lysate was purified by extraction with phenol:chloroform (1:1 v:v). The plasmid DNA was precipitated with 2 volumes of cold ethanol and the precipitate was centrifuged at $12000 \mathrm{rpm}$ at $4^{\circ} \mathrm{C}$ for $10 \mathrm{~min}$, washed with ethanol $70 \%$, dried and dissolved in TE buffer $(10 \mathrm{mM}$ TrisHC1, 1 mM EDTA, pH 8.0) $200 \mu$ l. Traces of RNA were digested with RNA-ase $0.1 \mu \mathrm{g} / \mathrm{ml}$ at $37^{\circ} \mathrm{C}$ for $30 \mathrm{~min}$.

\section{Restriction endonuclease analysis}

Restriction endonuclease analysis of the isolated plasmid samples was performed with the following enzymes: Ava II, Bam HI, Bg III, Bsp RI (Hae III isoschizomer), Hinc II, Hind III, Pst I, Sac I, Sac II, Sau96 I and Smal I in volumes of $20 \mu \mathrm{l}$, under the conditions recommended by the suppliers. In double digestions, the ionic strength was increased appropriately, or after precipitation of the nucleic acids, the reaction buffer was changed.

Purified plasmids and digestion mixtures were submitted to horizontal slab-gel electrophoresis in agarose $0.8 \%$ gels (containing ethidium bromide $0.5 \mu \mathrm{g} / \mathrm{ml}$ ) with TBE buffer (45 mM Tris-borate, $1 \mathrm{mM}$ EDTA, $\mathrm{pH}$ $8.25)$ at $3.3 \mathrm{~V} / \mathrm{cm}$. The molecular sizes of the plasmids and their fragments were determined from a calibration curve plotting the $\log _{10}$ of the size of molecular marker fragments against relative mobility.
The Pst I restriction fragments of phage $\lambda$ DNA were used as mol.wt standards. Two-dimensional agarose gel electrophoresis was carried out as described by Hintermann et al. (with minor modifications) [10]. Polyacrylamide gel electrophoresis was used to reveal suspected small fragments after Bsp RI (Hae III) endonuclease digestion [11].

\section{Antibiotic susceptibility testing}

Antibiotic resistance of the strains was determined by the micro-broth dilution method according to the NCCLS guidelines [12]. Toxin production by $B$. fragilis strains was investigated with HT29 cells as described previously [13]. Binding of extracellular matrix proteins to the surface of strains was investigated with a latex agglutination test [14].

\section{Results}

Low mol.wt plasmids $(2.8-11 \mathrm{~kb})$ were found in 33 $(48 \%)$ of the 69 isolates of pathogenic origin (Fig. 1) and $11(39 \%)$ of the 28 isolates of non-pathogenic origin (Tables 1 and 2). In seven isolates from both groups, high mol.wt $(>25 \mathrm{~kb})$ plasmid forms were also observed. Altogether 15 isolates ( 3 faecal isolates and 12 of pathogenic origin) contained more than one plasmid. When a strain harboured more than one plasmid, the exact plasmid profile was determined by two-dimensional agarose gel electrophoresis, which is suitable for the separation and recognition of different forms of each plasmid present. By these methods, the different plasmid types were determined according to their mol. wts $(2.8,3.4,4.2,5.0,5.5,6.0,7.6,9.3,10.0$ and $11.0 \mathrm{~kb}$ ). A comparison of the prevalence of plasmids in $B$. fragilis isolates of different origins (normal faecal flora and infections) and those belonging to species other than $B$. fragilis revealed no significant differences (33\% and $49 \%$ versus $46 \%$ and $44 \%$, respectively). In isolates from infectious processes, the $5.5-\mathrm{kb}$ plasmid was predominant being present in $24(35 \%)$ isolates, alone or together with other plasmids. It was also found in 5 of 28 isolates from faeces of healthy persons. The second most frequently isolated plasmid, with a mol.wt of $4.2 \mathrm{~kb}$, was more equally distributed among the isolates from the two groups ( 22 and $29 \%$ in isolates from infectious processes and from normal faecal flora, respectively).

To test whether the $5.5-\mathrm{kb}$ plasmids present in different isolates were similar, five $B$. fragilis isolates (K25, P27, P35, P36 and P66) and one B. vulgatus isolate (P61) containing only this plasmid were selected. As the alkaline/SDS lysis method used for plasmid screening usually yielded a low amount of plasmid DNA, the large scale plasmid isolation method described by Zöllner et al. [9], which gave plasmid DNA in sufficient quantity and purity, was used. Digestion with Ava II, Bsp RI (Hae III isoschi- 


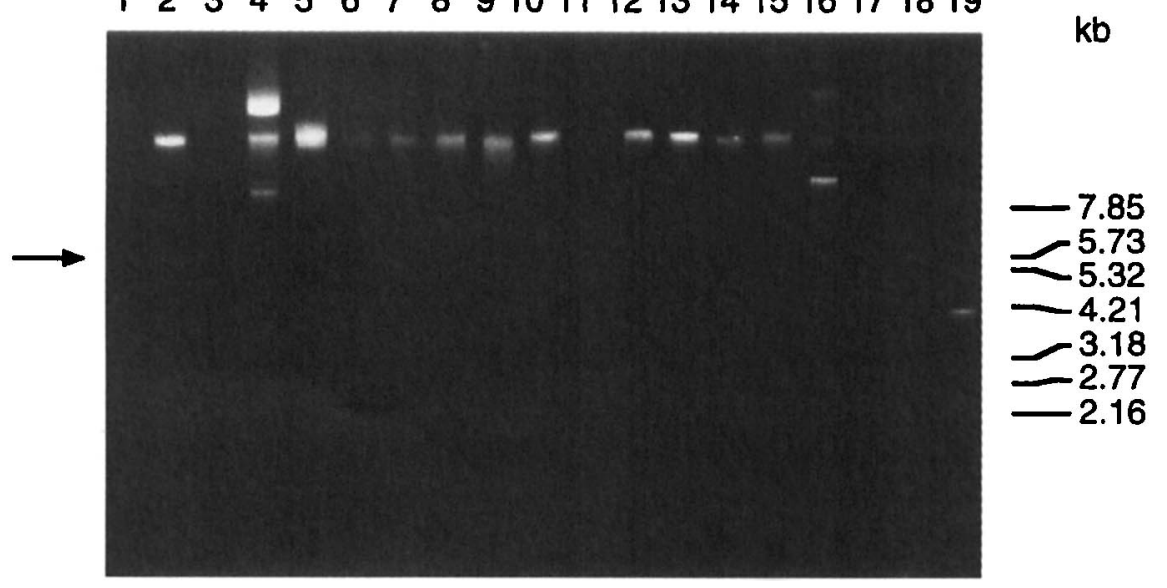

Fig. 1. Gel electrophoresis of representative plasmid preparations of Bacteroides isolates from infectious processes. Lanes 1-19, plasmid patterns of Bacteroides isolates P25, P27, P28, P29, P30, P31, P32, P33, P34, P35, P36, P37, $\mathrm{P} 38$, P61, P62, P63, P64, P66 and P67, respectively. The position of the 5.5-kb plasmid is indicated on the left, the position and mol.wt values $(\mathrm{kb})$ of the reference plasmids of $E$. coli strain $\mathrm{V} / 517$ are indicated on the right.

Table 1. Plasmid content, antibiotic resistance profile and enterotoxin production of Bacteroides isolates from the faeces of healthy persons

\begin{tabular}{|c|c|c|c|c|}
\hline $\begin{array}{l}\text { Isolate } \\
\text { designation }\end{array}$ & $\begin{array}{l}\text { Bacteroides } \\
\text { species }\end{array}$ & $\begin{array}{l}\text { Antibiotic resistance } \\
\text { pattern* }\end{array}$ & $\begin{array}{l}\text { Enterotoxin } \\
\text { production }\end{array}$ & $\begin{array}{l}\text { Plasmids } \\
\quad(\mathrm{kb})\end{array}$ \\
\hline F01 & B. fragilis & Amp, Cfx, Cln & - & 4.2 \\
\hline F03 & B. fragilis & Amp, Cfx, Cln, Tet & - & 4.2 \\
\hline F09 & B. fragilis & Amp & + & $49,33,10,4.2,3.4$ \\
\hline F10 & B. fragilis & Amp, Cfx, Tet & - & $25,5.5,4.2,3.4$ \\
\hline F31 & B. fragilis & Amp & - & 5.5 \\
\hline F13 & B. ovatus & Amp, Cfx, Cln, Tet & NT & 4.2 \\
\hline $\mathrm{F} 20$ & B. ovatus & Amp, Cln, Tet & NT & $10,5.5,4.2$ \\
\hline F11 & B. eggerthii & Amp, Tet & NT & 4.2 \\
\hline F16 & B. eggerthii & Amp, Cfx, Tet & NT & 4.2 \\
\hline F15 & Mitsuokella (B.) multiacida & Amp & NT & 5.5 \\
\hline $\mathrm{F} 18$ & B. vulgatus & Amp, Cln & NT & 5.5 \\
\hline
\end{tabular}

NT, not tested.

* The strains were considered resistant if their MIC values fell into the categories moderately resistant or resistant according to NCCLS standards [12] for the following antibiotics: ampicillin (Amp), cefoxitin (Cfx), imipenem (Imi), chloramphenicol (Cam), clindamycin (Cln), tetracycline (Tet), metronidazole (Met).

zomer), Sac I and Sau96 I resulted in the same size fragments for all six plasmids (Table 3, Fig. 2). Pst I digested only five of the six plasmids (Table 3 ). Splitting did not occur with Bam HI, BglII, Hinc II, Hind III, Sac II and Sma I in any case (Fig. 3). The relative positions of the recognition sites of cutting by restriction endonucleases on the plasmid molecules were mapped by means of single and double digestions. The restriction fragments obtained by double digestions were identical for the plasmids pBFK25, pBFP27, pBFP35, pBFP36 and pBFP66 from $B$. fragilis isolates. The Pst I recognition site was missing from the pBVP61 plasmid harboured by the $B$. vulgatus isolate (Fig. 4). As the Bsp RI (Hae III) fragments seen on agarose gel were not large enough to fill the entire $5.5-\mathrm{kb}$ plasmid size, smaller fragment(s) were searched for by polyacrylamide gel electrophoresis. Two such fragments were found that may be located between the Sac I and Ava II sites on the basis of the lacking fragment length in $B s p$ RI (Hae III) double digestions (Table 3).
No correlation was observed between plasmid profile and enterotoxin production in $B$. fragilis isolates originating from infectious processes or from the faeces of healthy persons (Tables 1 and 2), nor between plasmid profile and the binding capacity of fibronectin, vitronectin and collagen to different Bacteroides isolates from infections (Table 2). All but one strain in both groups were resistant to ampicillin. Clindamycin resistance in both groups was high (45\% and $27 \%$, respectively) (Tables 1 and 2 ) as was tetracycline resistance $(54 \%$ and $63 \%$, respectively). No correlation between resistance pattern and plasmid profile was apparent.

\section{Discussion}

A variety of low mol.wt plasmids is present in many Bacteroides strains originating from infections or from the normal faecal flora $[3-5,15]$. The prevalence of such plasmids varies according to the method used for 


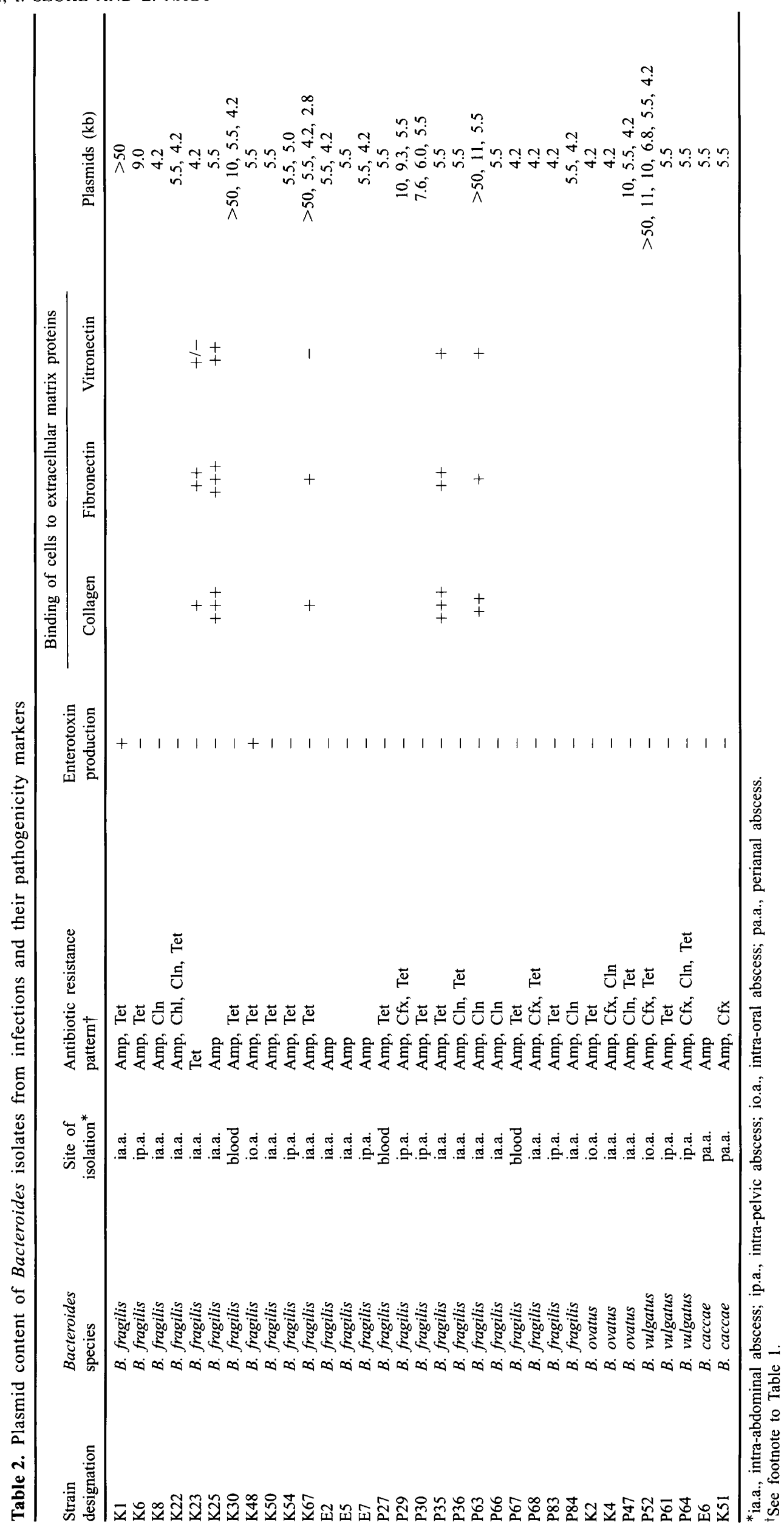


Table 3. Fragments produced by restriction endonuclease digestions of selected 5.5-kb plasmids

\begin{tabular}{|c|c|c|c|c|c|c|}
\hline \multirow[b]{2}{*}{ Endonuclease } & \multicolumn{6}{|c|}{ Lengths of fragments $(\mathrm{kb})$ from plasmids of the following isolates } \\
\hline & $\begin{array}{l}\text { B. fragilis } \\
\mathrm{K} 25\end{array}$ & $\begin{array}{l}\text { B. fragilis } \\
\text { P27 }\end{array}$ & $\begin{array}{l}\text { B. fragilis } \\
\text { P35 }\end{array}$ & $\begin{array}{l}\text { B. fragilis } \\
\text { P36 }\end{array}$ & $\begin{array}{l}\text { B. vulgatus } \\
\text { P61 }\end{array}$ & $\begin{array}{l}\text { B. fragilis } \\
\text { P66 }\end{array}$ \\
\hline Ava II & 5.5 & 5.5 & 5.5 & 5.5 & 5.5 & 5.5 \\
\hline Bam HI & - & - & - & - & - & - \\
\hline Bgl II & - & - & - & - & - & - \\
\hline \multirow{4}{*}{ Bsp RI (Hae III) } & 4.2 & 4.2 & 4.2 & 4.2 & 4.2 & 4.2 \\
\hline & 1.0 & 1.0 & 1.0 & 1.0 & 1.0 & 1.0 \\
\hline & 0.15 & 0.15 & 0.15 & 0.15 & 0.15 & 0.15 \\
\hline & 0.12 & 0.12 & 0.12 & 0.12 & 0.12 & 0.12 \\
\hline Hinc II & - & - & - & - & - & - \\
\hline Hind III & - & - & - & - & - & - \\
\hline Pst I & 5.5 & 5.5 & 5.5 & 5.5 & -* & 5.5 \\
\hline Sac 1 & 5.5 & 5.5 & 5.5 & 5.5 & 5.5 & 5.5 \\
\hline Sac II & - & - & - & - & - & - \\
\hline Sau96 I & 5.5 & 5.5 & 5.5 & 5.5 & 5.5 & 5.5 \\
\hline Sma I & - & - & - & - & - & - \\
\hline
\end{tabular}

- , no digestion.

${ }^{*}$ The result was confirmed by co-digestion with pUC19 DNA.

\section{$\begin{array}{llllllllllllll}1 & 2 & 3 & 4 & 5 & 6 & 7 & 8 & 9 & 1011 & 1213 & 141516 & 17 & 181920\end{array}$}

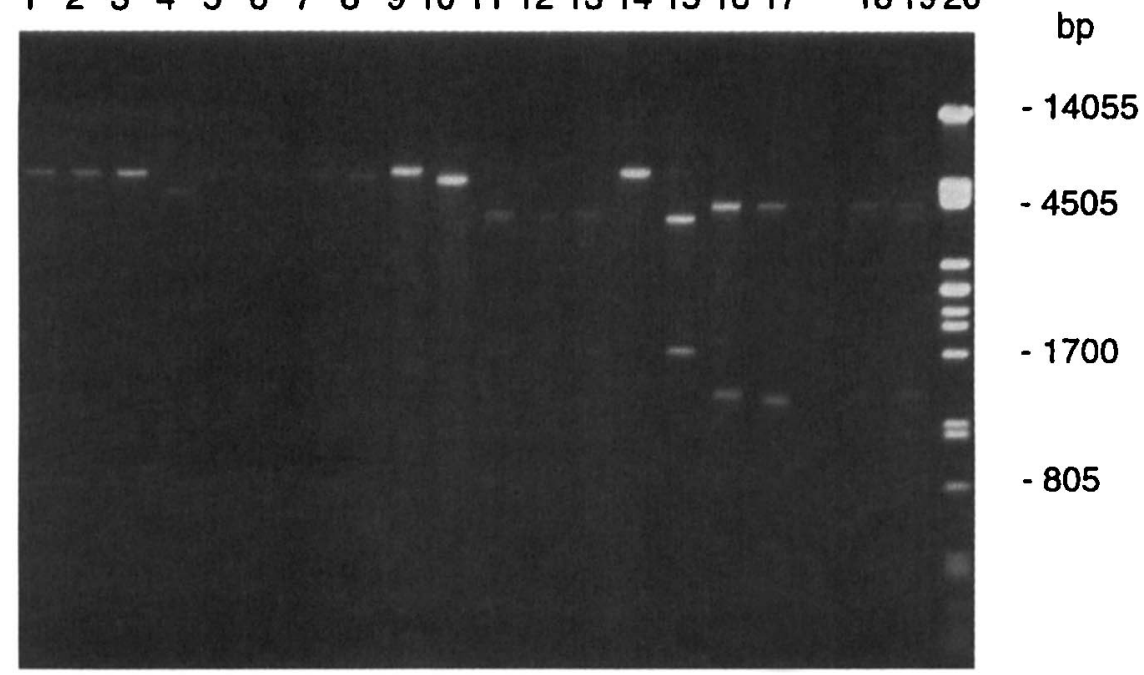

Fig. 2. Restriction endonuclease digestion and mapping of four 5.5-kb Bacteroides plasmids. Plasmid preparations that contained only a $5.5-\mathrm{kb}$ plasmid were digested with the following endonucleases: Pst I (lanes 1-5);Pst I + Ava II (610); Pst I + Sac I (11-15); $A v a \mathrm{II}+$ Sac I (16-19). Plasmid preparations from the following strains were used: $B$. fragilis $\mathrm{P} 27(\mathbf{1 , 6}, \mathbf{1 1}, \mathbf{1 6}) ; B$. fragilis $\mathrm{P} 35(\mathbf{2}, \mathbf{7}, \mathbf{1 2}, \mathbf{1 7}) ; B$. fragilis $\mathrm{P} 36(\mathbf{3}, \mathbf{8}, \mathbf{1 3}) ;$ B. vulgatus $\mathrm{P} 61(4,9,14,18) ; B$. fragilis P66 $(5, \mathbf{1 0}, \mathbf{1 5}, \mathbf{1 9})$. Pst I restriction fragments of phage $\lambda$ DNA (20) were used as molecular size marker (sizes in $\mathrm{kb}$ of some marker fragments are indicated on the right).

their isolation and the origin of the isolates. With the lysozyme/SDS isolation method, Wallace et al. [3] found that $25 \%$ of 32 randomly selected clinical Bacteroides isolates contained plasmids of three different mol. wts (5.0, 3.0 and 2.0 MDa). Beul et al. [15] presumed that Bacteroides cells were resistant to lysozyme, and applied the heat/mild alkaline/SDS method to 26 clinical isolates, 24 of which were $B$. fragilis. Eleven isolates (42\%) contained one or several (up to three) plasmids of different sizes. Plasmids of similar size showed identical restriction patterns with 17 restriction endonucleases. The most frequently found plasmid size was $3.6-\mathrm{kb}$. Only one $B$. fragilis isolate contained a $4.2-\mathrm{kb}$ plasmid together with two other plasmids. Callihan et al. [5] tested clinical isolates and isolates from the normal faecal flora. When the high salt precipitation method was used, 15 $(44 \%)$ (two B. thetaiotaomicron and 13 B. fragilis) of 34 isolates exhibited plasmids of small size. Three classes of plasmids were identified by Southern hybridisation. Plasmids with a mol.wt of $5.5 \mathrm{~kb}$ were found in only two $B$. fragilis isolates. When plasmids were isolated by the lysozyme/SDS/high salt precipitation method, a plasmid of the same size $(5.5 \mathrm{~kb})$ was found in 17 Bacteroides isolates ( $B$. fragilis, $B$. thetaiotaomicron and $B$. vulgatus) among 26 plasmidbearing clinical isolates in Hungary [4].

The present study confirms the wide distribution $(66 \%$ of the plasmid-bearing strains) of a $5.5-\mathrm{kb}$ plasmid 
123456789101112131415161718192021

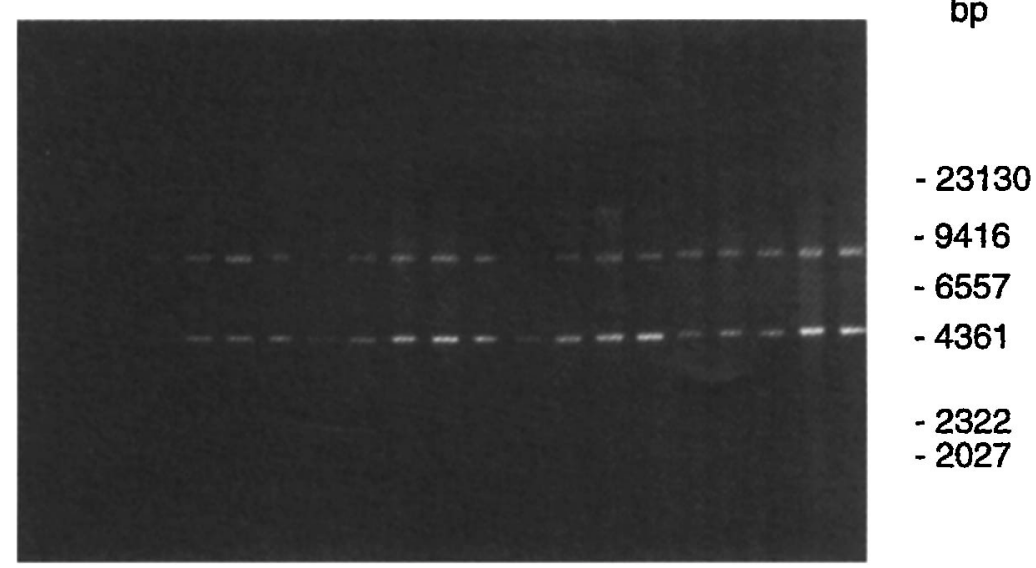

Fig. 3. Results of restriction endonuclease treatment of five $5.5-\mathrm{kb}$ plasmids from Bacteroides isolates by restriction endonucleases that do not cut these plasmids: Sac II (lanes 2-6); Sma I (7-11); Bam HI (12-16); Bgl II (17-21). Lane 1 , undigested 5.5-kb plasmid DNA from $B$. vulgatus P61 strain. Plasmid preparations from the following strains were used: B. fragilis $\mathrm{P} 27$ (lanes 2, 7, 12, 17); B. fragilis P35 (3, 8, 13, 18); B. fragilis $\mathrm{P} 36(\mathbf{4}, \mathbf{9}, \mathbf{1 4}, \mathbf{1 9})$; B. vulgatus $\mathrm{P} 61$ $(5,10,15,20) ; B$. fragilis $\mathrm{P} 66(\mathbf{6}, \mathbf{1 1}, \mathbf{1 6}, \mathbf{2 1})$. Positions of phage $\lambda$ DNA Hind III restriction fragments are indicated on the right.

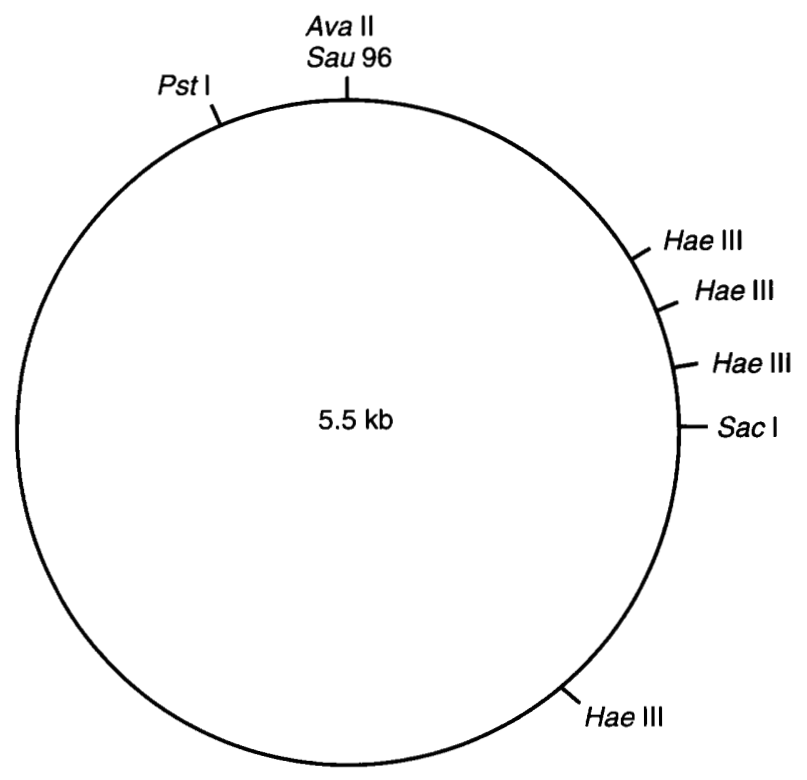

Fig. 4. Restriction map of the 5.5-kb plasmid pBFP36. No recognition sites were found for $B a m \mathrm{HI}, B g l \mathrm{II}$, Hinc II, Hind III, Sac II and Sma I.

among Bacteroides spp., both clinical isolates as well as isolates from faecal samples from healthy persons. The isolates that harboured this plasmid belonged to different species of Bacteroides. The homology of six isolated plasmids of this type is suggested by restriction endonuclease analysis. The six plasmids, originating from five $B$. fragilis and one $B$. vulgatus isolates, were identical, except that the $B$. vulgatus plasmid pBVP61 did not have a recognition site for Pst I. This could be due to a point mutation in the Pst I recognition site or probably methylation of the Pst I site. The physical map of the $5.5-\mathrm{kb}$ plasmid in the present study corresponded closely to that obtained by Beul et al. [15] for the 5.5-kb plasmid present in
German isolates. These $5.5-\mathrm{kb}$ plasmids of Bacteroides spp. may represent a uniform and homologous plasmid type present in strains isolated in different parts of the world.

The second most frequently found plasmid in this study was $4.2 \mathrm{~kb}$ in size and was present in 23 of 44 plasmid-bearing isolates. Plasmids of the same mol. wt were found in Prevotella melaninogenica [16] and in one $B$. fragilis strain investigated by Beul et al. [15]. A 4.2-kb cryptic Bacteroides plasmid pB8-51 was also found in several colonic Bacteroides spp. in the USA [9] and could be mobilised by $\mathrm{Tc}^{\mathrm{r}}$ conjugal elements and the conjugal plasmid pBF4, which carry a gene that encodes resistance to clindamycin and erythromycin.

The frequent presence of cryptic, low mol.wt plasmids in Bacteroides strains and in other gramnegative anaerobes, such as Prevotella spp. irrespective of whether they originate from normal flora or from infections, could not be correlated with any pathogenetic marker. In the present study, the $B$. fragilis isolates tested for the presence of plasmids were also tested for the presence of enterotoxin production, and all Bacteroides isolates from infections were tested for binding to matrix proteins such as fibronectin, vitronectin and collagen. No correlation was found.

The high frequency of tetracycline $(53-65 \%)$ and clindamycin $(21-27 \%)$ resistance among Hungarian isolates of Bacteroides isolates from infectious processes has been observed previously [17]. In the current study, $67 \%$ and $45 \%$ of 28 Bacteroides isolates from normal faeces showed resistance to tetracycline and to clindamycin, respectively. 
The occurrence of small, cryptic plasmids with the same molecular size in different Bacteroides strains in different parts of the world may be due to their horizontal mobilisation by several different conjugative elements $[6,18,19]$, which may promote their spread among normal flora. However, the wide distribution of these plasmids may signal a potential problem if they acquire antibiotic resistance or pathogenicity determinants which may render the treatment of bacteroides infections more difficult.

This study was partly supported by Hungarian research grants OTKA T01622 and MKM473.

\section{References}

1. Finegold SM, George WL. Anaerobic infections in humans. San Diego, CA, Academic Press. 1989.

2. Woese CR, Kandler O, Wheelis ML. Towards a natural system of organisms: proposal for the domains Archea, Bacteria, and Eucarya. Proc Natl Acad Sci USA 1990; 87: 4576-4579.

3. Wallace BL, Bradley JE, Rogolsky M. Plasmid analyses in clinical isolates of Bacteroides fragilis and other Bacteroides species. J Clin Microbiol 1981; 14: 383-388.

4. Nagy E, Dányi É, Földes J. Plasmid analysis of clinical isolates of Bacteroides fragilis group strains. Acta Microbiol Hung 1990; 37: 367-373.

5. Callihan DR, Young FE, Clark VL. Identification of three homology classes of small, cryptic plasmids in intestinal Bacteroides species. Plasmid 1983; 9: 17-30.

6. Valentine PJ, Shoemaker NB, Slayers AA. Mobilization of Bacteroides plasmids by Bacteroides conjugal elements. $J$ Bacteriol 1988; 170: 1319-1324.

7. Summanen P, Baron EJ, Citron DM, Strong CA, Wexler HM,
Finegold SM. Wadsworth anaerobic bacteriology manual, 5th edn. Belmont, CA, Star. 1993.

8. Birnboim HC, Doly J. A rapid alkaline extraction procedure for screening recombinant plasmid DNA. Nucleic Acids Res 1979; 7: $1513-1523$

9. Zöllner EJ, von Eichel-Streiber C, Schwindling FP. Isolation and purification of plasmids from Bacteroides fragilis using rubidium trichloroacetate density gradient centrifugation. $\mathrm{Mol}$ Gen Genet 1983; 189: 169-171.

10. Hintermann G, Fischer H-M, Crameri R, Hütter R. Simple procedure for distinguishing $\mathrm{CCC}, \mathrm{OC}$, and $\mathrm{L}$ forms of plasmid DNA by agarose gel electrophoresis. Plasmid 1981; 5: $371-373$.

11. Sambrook J, Fritsch EF, Maniatis T. Molecular cloning: a laboratory manual, 2nd edn. Cold Spring Harbor, NY, Cold Spring Harbor Laboratory Press. 1989.

12. National Committee for Clinical Laboratory Standards. Methods for antimicrobial susceptibility testing of anaerobic bacteria, 3rd edn; Approved Standard M11-A3. Villanova, PA, NCCLS. 1993.

13. Szöke I, Dósa E, Nagy E. Enterotoxigenic Bacteroides fragilis in Hungary. Anaerobe 1997; 3: 87-89.

14. Szöke I, Pascu C, Nagy E, Ljung $\AA$, Wadström T. Binding of extracellular matrix proteins to the surface of anaerobic bacteria. J Med Microbiol 1996; 45: 338-343.

15. Beul HA, von Eicher-Streiber $\mathrm{C}$, Schreiner $\mathrm{M}$ et al. Characterisation of cryptic plasmids in clinical isolates of Bacteroides fragilis. J Med Microbiol 1985; 20: 39-48.

16. Vandenbergh PA, Syed SA, Gonzales CF, Loesche WJ, Olsen RH. Plasmid content of some oral microorganisms isolated from subgingival plaque. J Dent Res 1982; 61: 497-501.

17. Nagy E, Szöke I, Gacs M, Csiszár K. Antibiotic susceptibility of Bacteroides fragilis group strains in Hungary. Anaerobe 1995; 1: 269-274.

18. Smith JC, Parker AC. A gene product related to Tral is required for the mobilization of Bacteroides mobilizable transposons and plasmids. Mol Microbiol 1996; 20: 741-750.

19. Stiffler PW, Keller R, Traub N. Isolation and characterization of several cryptic plasmids from clinical isolates of Bacteroides fragilis. $J$ Infect Dis 1974; 130: 544-548. 